\title{
Effects of Adherence to Environmental Rules and Regulations in Stone Quarrying at Tuluongoi Sublocation of Baringo County, Kenya
}

\author{
Caroline J. Kibii* and Isaac Ndolo \\ Department of Geography and Environmental Studies, University of Nairobi
}

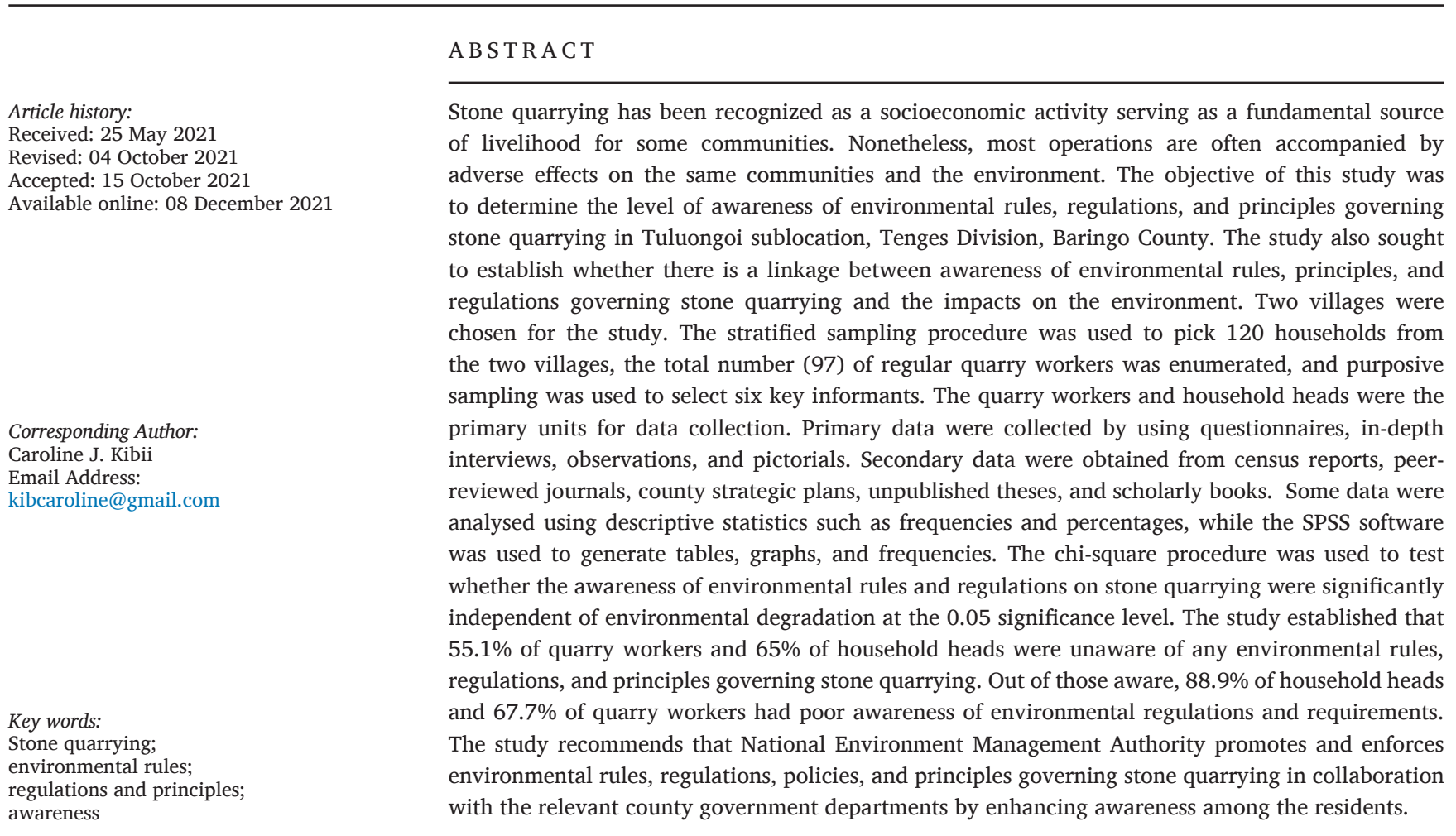

\section{Introduction}

Stone quarrying has played a significant role in boosting local economies globally for several years (Natural Environment Research Council, 2017). The continued global population growth has propelled an increase in stone quarrying to fulfil the building and construction needs of the population (Lad and Samant, 2014). As a result, several stone quarries have emerged, posing a threat to human and environmental health (Kumar et al., 2014).

Stone quarrying in Kenya has been taking place for decades. The frequency of stone quarrying has significantly gone up recently due to the increasing population that prompted a high demand for housing, especially in the urban areas (
Adimo et al., 2018). The high demand for building stones in Kenya and Tanzania is the reason illegal stone quarrying sites have been established in some unregulated areas (Wells and Wall, 2001). A 2020 audit report on land conservation and restoration of quarries in Kenya revealed that unregulated quarrying activities adversely affect the environment (Auditor General, 2020).

According to Mhlongo and Amponsah-Dacosta (2016), different quarrying sites manifest different levels of impacts on human development and the environment. Stone quarrying is associated with both positive and negative effects on social and environmental well-being (Endalew et al., 2019). While stone quarrying has contributed to economic and societal development, it has aggravated harm to human health 
and the ecosystem, especially when quarries are abandoned.

Dust emissions from quarrying operations and hauling affect the air quality of a local area, eventually implicating human health (Tribhuwan and Patil, 2009; Lad and Samant, 2014). Blasting stones and rocks leaves scars and ugly holes on hillsides and the ground, respectively (Bowen and Pallister, 2006). Similarly, quarrying activities intensify scars on unrepaired land in quarried zones (Adimo et al., 2018). Report by the International Conference on Land Degradation as described by Zdruli et al. (2010) maintains that decades of unregulated quarries to support urban and industrial development have left multitudes of scars on the land depriving the environment of its aesthetic integrity as per Tsolaki-Fiaka et al. (2018).

Essentially, quarrying activities are governed by principles, laws, and regulations that must be adhered to. Increased awareness of environmental laws, policies and regulations promote compliance and adherence (Smith and Rosenblum, 2011). Twerefou et al. (2015) posited that communicating the possible adverse effects of a quarry or a mine on human health and the environment before the start of operations influences people's uptake and views towards policies and interventions.

Lad and Samant's (2014) study uncovered that none of the quarry workers and the locals had any clue of the status of the quarries or the rules and regulations governing the quarrying operations. In addition, Twerefou et al. (2015) indicate that the social and economic pressures affecting a community dictate their attitudes towards the extractive industry's policies and regulations.

A study conducted in Ndarugu, Kiambu, Kenya, demonstrated that large parts of quarried areas are unrestored, citing inefficient legal procedures and many landowners lacking the awareness of the need to rehabilitate quarried lands (Adimo et al., 2018).

Kenya has principles, laws, and policies governing quarrying operations, such as the Kenya National Environment Management Authority's 2011 integrated national land-use guidelines. The document outlines several quarrying operational principles, such as the need for an environmental impact assessment before quarrying begins (NEMA, 2011). Besides, section 101 (1) of the occupational health and safety act no. 15 of 2007 (revised in 2010) requires every employer to provide and maintain protective clothing and appliances for employees involved in injurious or offensive substances and activities. The Mining Act, 2016 regulates quarrying operations in Kenya.

The National Environment Policy (NEP) 2013 acknowledges the vitality of environmental education, both formal and informal, to raise awareness and change the public's attitude and enhance a sense of responsibility on ecological matters. The policy also alludes that communicating environmental information to all persons is still a pressing problem (NEP, 2013).

Considerably, Baringo County Integrated Development Plan (2018-2022) lists Tuluongoi location, where the study area is, as the primary source of building and extraction stones in Baringo County (BCG, 2018). Despite that, the county lacks a quarrying and mining policy; no environmental impact assessment has been done to ascertain the social and environmental challenges from the quarrying operations. Further, no similar study has been conducted in the area regardless of the worth of stone quarrying to the county's social and economic development.

Previous studies have extensively focused on the essentiality of enforcing and implementing environmental rules, principles, and regulations guiding the quarrying operations (Hamza and Kanyama, 2016; Mwakumanya, 2014). However, most research ignores the significance of awareness of existing legal and institutional frameworks on quarrying construction stones and its relation to the magnitude of degradation and rehabilitation of quarried areas. This study sought to establish the awareness level of existing environmental rules, regulations, and principles governing stone quarrying in Tuluongoi sublocation and whether it is linked to the severity of degradation of the environment. The study concluded that awareness of the rules, regulations, and principles have a significant influence on environmental degradation in the study area.

\section{Materials and methods}

\subsection{Study Area}

The study was carried out in two villages and three quarrying sites of Tuluongoi Sublocation in Tenges Division Baringo County, Kenya. Baringo County is one of the forty-seven counties in Kenya located in the former Rift Valley Province with six administrative areas (Fig. 1). Tuluongoi sublocation is approximately 16.5 square kilometers with a population of 1501 (Kenya National Bureau of Statistics, 2015). Tuluongoi sublocation is hilly and rocky and known for small-scale farming and intense unregulated quarrying of building and construction stones used within and out of the County.

\subsection{Data and sampling}

Primary and secondary data sources were used for this study, where secondary data were obtained from sources such as government reports, journals, unpublished theses, and academic books.

Primary data were obtained through the use of interviews, questionnaires, photographs, and observations. Questionnaires were administered to the household respondents and selected quarry workers; the questions were both open-ended and closed-ended. In-depth interviews were administered to the key informants. Respondents were interviewed at their homes and workplaces.

Photographs were used to enhance the research. Observation method was used to gather information of activities within the quarrying areas and the surrounding environment such as the stone waste, abandoned quarries, and damage on vegetation, dust, and general outlook of the quarrying sites to enable informed judgments when discussing the findings.

The stratified sampling procedure was used to pick 120 households from the two villages, Sangarau and Ketorit, while census was used to enumerate 97 regular quarry 


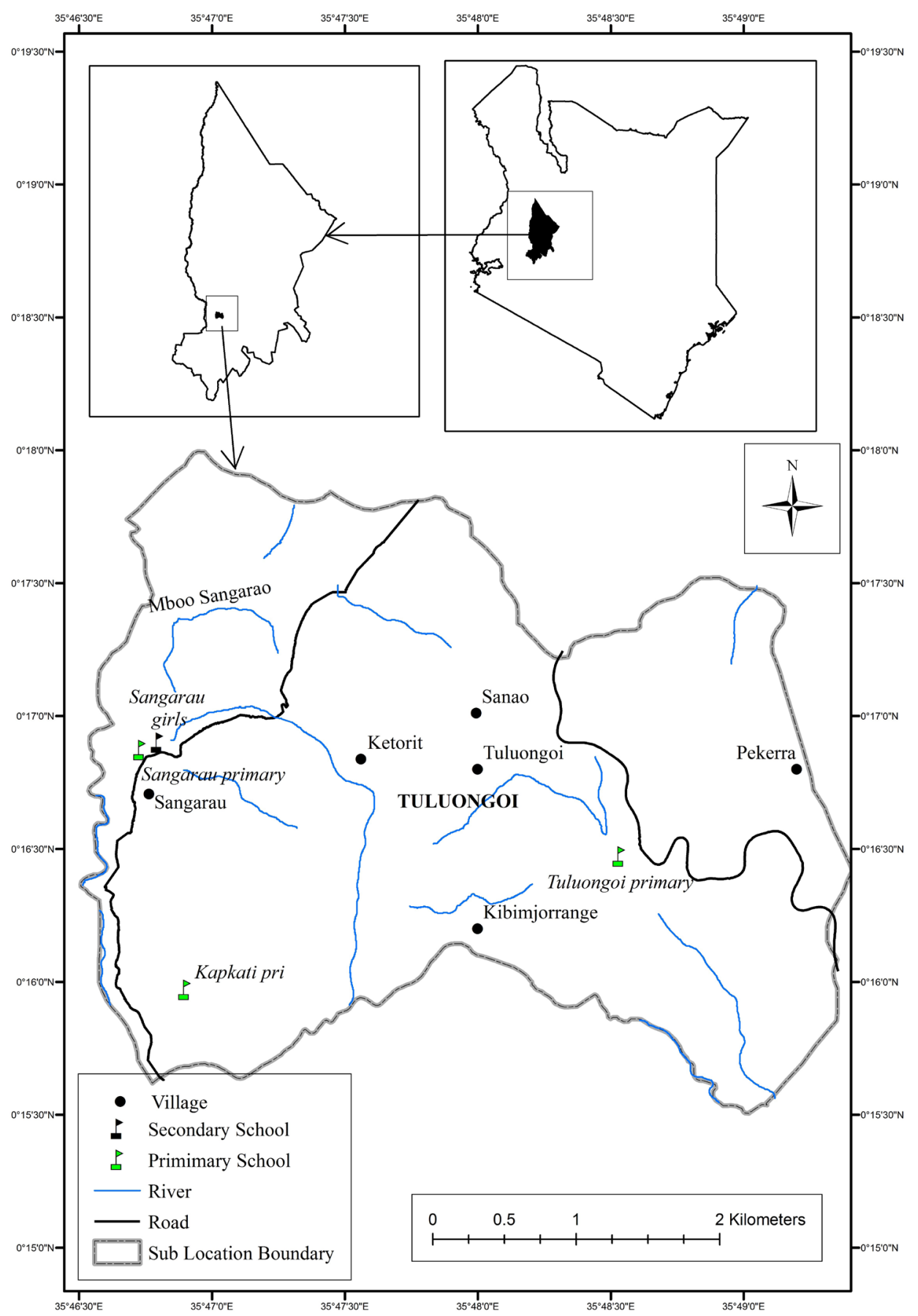

Fig. 1. Map of Kenya showing the two villages picked for the study Source: Researcher (2019)

workers from three sites, namely Ketorit, Chemos and Sangarau. Purposive sampling was used to pick key informants who were: 2 healthcare practitioners from Tenges health facility, 1 NEMA official, 3 quarry managers and the county director Department of Mining.

The study applied the Yamane (1967) formula based on a $95 \%$ confidence level or 0.05 rejection level to determine the sample size of the households from a population of 172 households in the study area.

The sample size was determined as follows:

$$
n=\frac{N}{1+N\left(e^{2}\right)}
$$

Where;

$\mathrm{n}=$ the sample size

$\mathrm{N}=$ the size of the population

$\mathrm{e}=$ Error margin or the precision level desired or the significance level which is 0.05 ( $95 \%$ confidence level).

Using the formula yields a sample size of 120 .

The samples from the two villages were proportionately de- 
termined as shown below;

Sampled household heads per village $(\mathrm{n})=$ (number of household heads per village/total number of household heads) *120, hence, Ketorit $n=54$ and Sangarau $n=66$. Descriptive and inferential statistics were used to analyse the field data. The SPSS software was used to process the data and output presented in tables, charts, and graphs. The study used chi-square, to test the formulated null hypothesis where cross-tabulation was performed to depict the relationship between and among the investigated variables.

\section{Results and discussion}

\subsection{Awareness of any Environmental Rules, Principles and Regulations on Stone Quarrying}

From the findings, $44.9 \%$ of the quarry workers and $35.0 \%$ of the household heads were aware of at least one of the existing environmental rules, principles and regulations governing stone quarrying outlined under NEMA's 2011 integrated national land-use guidelines. The findings implied that a significant proportion of the respondents were unaware of any environmental rules and regulations guiding stone quarrying, consistent with the observations made by Lad and Samant (2014) that many quarry workers and locals in most cases have no clue of the permissible quarrying standards as well as the rules and regulations governing the quarrying operations.

Tables 1 and 2 summarises the various guidelines, rules, principles, and regulations that the quarry workers and household heads mentioned about awareness respectively.

Table 1. Response by quarry workers on awareness of rules, regulations, principles and guidelines on stone quarrying.

\begin{tabular}{lcc}
\hline $\begin{array}{l}\text { Rules, regulations, principles and } \\
\text { guidelines }\end{array}$ & $\begin{array}{c}\text { Frequency } \\
(\mathbf{n}=\mathbf{3 1})\end{array}$ & Percent \\
\hline $\begin{array}{l}\text { Do not destroy vegetation, trees when } \\
\text { quarrying }\end{array}$ & 7 & 22.6 \\
$\begin{array}{l}\text { After quarrying, the land should be } \\
\text { reclaimed }\end{array}$ & 3 & 9.7 \\
$\begin{array}{l}\text { Do not dig more than } 8 \text { feet deep } \\
\begin{array}{l}\text { Do not quarry near water sources, avoid } \\
\text { siltation }\end{array}\end{array}$ & 28 & 90.3 \\
$\begin{array}{l}\text { Rehabilitation of quarries after quarry- } \\
\text { ing, fill up the holes }\end{array}$ & 11 & 35.5 \\
$\begin{array}{l}\text { Use of environmentally friendly tools } \\
\text { Planting trees after quarrying }\end{array}$ & 6 & 19.4 \\
$\begin{array}{l}\text { Limited noise and vibration } \\
\text { Do not quarry in the forest and hills }\end{array}$ & 8 & 48.4 \\
\hline
\end{tabular}

\subsection{Awareness of Environmental Rules, principles and Regulations on Stone Quarrying}

The level of awareness of the existing rules, regulations, and principles governing stone quarrying was crucial in this study.

Table 2. Adherence to rules, regulations, principles and guidelines by household heads

\begin{tabular}{lcc}
\hline $\begin{array}{l}\text { Rules, regulations, principles, guide- } \\
\text { lines }\end{array}$ & $\begin{array}{c}\text { Frequency } \\
(\mathbf{n}=\mathbf{3 6})\end{array}$ & Percent \\
\hline $\begin{array}{l}\text { Do not destroy vegetation or cut trees } \\
\text { when quarrying }\end{array}$ & 29 & 80.6 \\
$\begin{array}{l}\text { Do not quarry near water catchment } \\
\text { areas }\end{array}$ & 17 & 47.2 \\
$\begin{array}{l}\text { Depleted holes should be filled after } \\
\text { quarrying activities }\end{array}$ & 4 & 11.1 \\
\hline
\end{tabular}

The results shown in Fig. 2 illustrate the awareness level of those respondents that were aware of at least one rule, regulation, or principle. The majority of the quarry workers and household heads, $67.7 \%$ and $88.9 \%$, respectively, demonstrated that their awareness level was poor, with only 9.7\% of the quarry workers indicating a good awareness level; no household head good awareness. The awareness level was tested based on the interaction and knowledge of the existing rules, laws and regulations. For instance, poor awareness level meant that an individual had come across at least one law, regulation or principle but had no idea of the specific details. Therefore, a population where a majority of its members have insufficient knowledge of the legal and institutional frameworks fails to observe or implement policies, laws and regulations fully effectively.

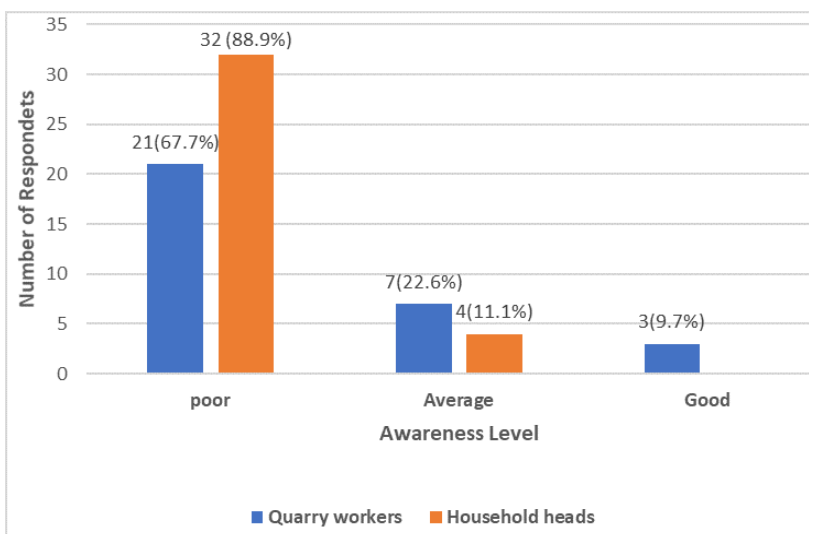

Fig. 2. Awareness level of existing environment rules, principles and regulations on stone quarrying Source: Field Data (2020)

\subsection{Reponses to Statements Relating to Environmental Rules/Regulations on Stone Quarrying}

The quarry workers and household heads were presented with various statements relating to the existing environmental laws, rules, regulations, and operation principles concerning stone quarrying in Kenya adapted from NEMA's 2011 integrated national land-use guidelines on quarrying operations. The results are presented in Tables 3 and 4. Only $13.0 \%$ of the quarry workers and $5.8 \%$ of the household 
heads were aware that an environmental impact assessment should be carried out prior to the commencement of a quarrying process. The low outcome is despite a mandatory integrated environmental impact assessment outlined under EMCA 1999/2015. The result illustrates a lack of enforcement and implementation of the relevant policies, rules and regulations, which partly influence the nature and extent of quarrying implications on the social and environmental facets of the community.

From the study, only $23.2 \%$ of quarry workers and $6.8 \%$ of household heads were aware that all persons working in a quarry must adorn protective gear. In addition, $84.1 \%$ of all the quarry workers interviewed did not use any protective equipment, with the majority arguing that the area was very hot and due to the nature of their work, they would sweat a lot, thus disregarded helmets and boots. The quarry workers also claimed that none of their employers provided protective gears forcing them to convert their clothes into nose or mouth masks when blasting and dry seasons because the dust is always up. The finding is contrary to sections 99 and 101 of Kenya's occupational safety and health Act No. 15 of 2007 (Revised 2010) that requires employers to provide their employees working in quarries with protective gear and first aid kits.

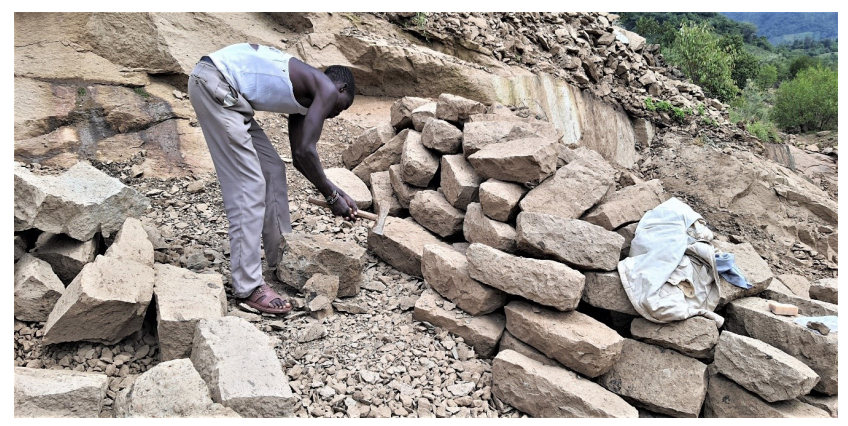

Plate 1: A quarry worker in Sangarau site going about his daily activities without protective gear

Source: Field data (2020)

The study revealed that $36.2 \%$ of quarry workers and $28.2 \%$ of household heads knew that quarrying should be done 50m away from homes. However, most of the respondents were quick to disclaim that they were not sure of the exact allowable distance claiming that in some instances, quarrying took place up to less than $10 \mathrm{~m}$ away from homes. The disclaim shows that the residents of Tuluongoi sublocation have not been educated on the existing environmental laws, principles and regulations governing stone quarrying. The national integrated land-use guidelines of 2011 outline that quarrying operations without blasting should be $50 \mathrm{~m}$ away from any house irrespective of the owner's consent (NEMA, 2011). Further, it emerged from this study that Baringo County has no quarrying and mining policy explaining the high number of respondents with low awareness of the quarrying guidelines and regulations.

The study further established that $30.4 \%$ of the quarry workers and $19.4 \%$ of the household heads were aware that all quarry sites must be fenced. Despite the knowledge, none of the quarrying sites were fenced. Quarrying in Ketorit site had resulted in the deaths of young children hit by rocks while walking, which is attributed to lack of fencing. In addition, livestock grazing and crisscrossing the quarrying site got injured, an incident that could have been prevented if the sites were fenced as per guidelines and regulations. Besides, $31.5 \%$ of the quarry workers and $17.5 \%$ of the household heads were aware of the need for warning signs at the site entry points.

Table 3: Quarry workers' Responses on Statements Relating to Existing Environmental Rules, Principles and Regulations on Stone Quarrying

\begin{tabular}{|c|c|c|c|c|}
\hline \multirow{2}{*}{ Statements (NEMA 2021) } & \multicolumn{2}{|c|}{ Aware } & \multicolumn{2}{|c|}{ Unaware } \\
\hline & Count & $\%$ & Count & $\%$ \\
\hline $\begin{array}{l}\text { An environmental impact as- } \\
\text { sessment should be performed } \\
\text { prior to quarrying begins in a } \\
\text { given place. }\end{array}$ & 9 & 13.0 & 60 & 87.0 \\
\hline All quarry sites must be fenced. & 21 & 30.4 & 48 & 69.6 \\
\hline $\begin{array}{l}\text { Depleted quarries should be re- } \\
\text { habilitated by the land owners. }\end{array}$ & 13 & 18.8 & 56 & 81.2 \\
\hline $\begin{array}{l}\text { All persons working at the } \\
\text { quarry sites should be provided } \\
\text { with protective gear and first } \\
\text { aid kits. }\end{array}$ & 16 & 23.2 & 53 & 76.8 \\
\hline $\begin{array}{l}\text { Quarrying operation should be } \\
\text { done } 50 \mathrm{~m} \text { away from homes. }\end{array}$ & 25 & 36.2 & 44 & 63.8 \\
\hline $\begin{array}{l}\text { Warning signs should be erect- } \\
\text { ed at the entry point of each } \\
\text { quarry site. }\end{array}$ & 22 & 31.9 & 47 & 68.1 \\
\hline
\end{tabular}

Source: Field Data (2020)

Table 4: Household heads' Responses on Statements Relating to Existing Environmental Rules, Principles and Regulations on Stone Quarrying

\begin{tabular}{|c|c|c|c|c|}
\hline \multirow{2}{*}{ Statements (NEMA 2021) } & \multicolumn{2}{|c|}{ Aware } & \multicolumn{2}{|c|}{ Unaware } \\
\hline & Count & $\%$ & Count & $\%$ \\
\hline $\begin{array}{l}\text { An environmental impact as- } \\
\text { sessment should be performed } \\
\text { prior to quarrying begins in a } \\
\text { given place. }\end{array}$ & 6 & 5.8 & 97 & 94.2 \\
\hline All quarry sites must be fenced. & 20 & 19.4 & 83 & 80.6 \\
\hline $\begin{array}{l}\text { Depleted quarries should be re- } \\
\text { habilitated by the land owners. }\end{array}$ & 33 & 32.0 & 70 & 68.0 \\
\hline $\begin{array}{l}\text { All persons working at the } \\
\text { quarry sites should be provided } \\
\text { with protective gear and first } \\
\text { aid kits. }\end{array}$ & 7 & 6.8 & 96 & 93.2 \\
\hline $\begin{array}{l}\text { Quarrying operation should be } \\
\text { done } 50 \mathrm{~m} \text { away from homes. }\end{array}$ & 29 & 28.2 & 74 & 71.8 \\
\hline $\begin{array}{l}\text { Warning signs should be erect- } \\
\text { ed at the entry point of each } \\
\text { quarry site. }\end{array}$ & 18 & 17.5 & 85 & 82.5 \\
\hline
\end{tabular}

Source: Field Data (2020) 
Nonetheless, no warning signs had been erected in any of the three quarrying sites contrary to the stipulations under the existing quarrying guidelines and principles, indicating poor or lack of enforcement. Mwakumanya (2014) recommends that proper enforcement of environmental laws, policies, and regulations reduces negative implications common in the extractive sector. Proper implementation strengthens awareness.

\subsection{Adherence to Relevant Environmental Rules, Princi- ples and Regulations}

From the study, $65.2 \%$ of the quarry workers and $59.2 \%$ of the household heads believed that quarrying activities in Tuluongoi sublocation did not adhere to any environmental principles, rules and regulations. It can be deduced from the findings that stone quarrying operations in the study area were carried out without adherence or compliance with the stipulated environmental rules and regulations on stone quarrying, a conclusion backed by the low awareness of the legal structures and illegality of the ongoing operations. According to Kindiga (2017), quarrying activities are governed by principles, laws, and regulations that must be adhered to. A community with in-depth knowledge of the quarrying regulations increases the ability of quarry owners to operate within the mandated laws. The findings agree with Twerefou et al. (2015), who noted that though a significant percentage of quarry workers were always aware that their actions should not harm the environment, they did not comply with the set standards.

A few household heads noted that the $50 \mathrm{~m}$ quarrying distance from homes was observed in some cases, primarily when the landowners or neighbours raised the alarm. However, the majority decried that the rules were not observed and that quarry workers were more interested in the gains while neglecting the social and environmental implications of stone quarrying. Some household heads recognized the efforts of a few quarry workers that refilled depleted quarries, although it was done to a small extent and when forced. Furthermore, the household respondents argued that due to their low awareness of the law, they assumed the quarry workers and quarry owners adhered to the rules and regulations because no one had ever been incriminated, fined, or arrested in relation to quarrying operations.

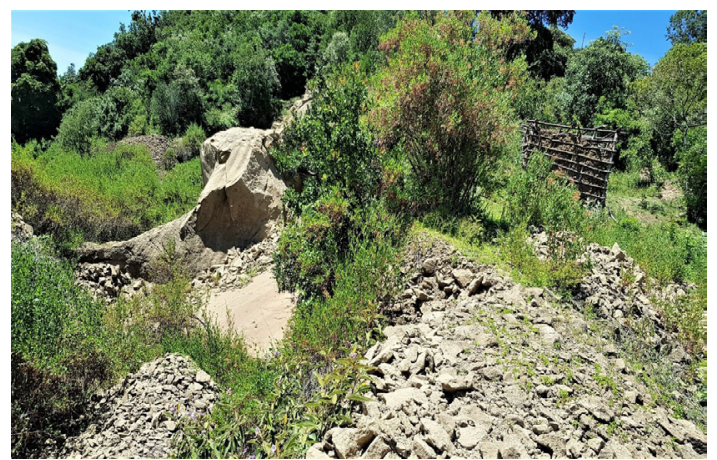

Plate 2: An abandoned quarry close to an old house structure

\subsection{Linkage between Awareness of Environmental Rules and Regulations and Existing Environmental Impacts of Stone Quarrying}

The study findings established that $56.5 \%$ of the quarry workers and $70.9 \%$ of the household heads agreed that there was a linkage between awareness of environmental rules, principles, and regulations governing stone quarrying and the current ecological impacts occasioned by quarrying operations. Adimo et al., 2018 observed that large proportions of quarried lands were not restored in many quarrying areas because many landowners lacked the awareness of the essence to rehabilitate and restore quarried land, thus calling for awareness creation and capacity building on quarry restoration procedures. Similarly, Hamza and Kanyama (2016) explained that the lack of understanding of the environmental impacts of stone quarrying and the relevant rules to protect the environment was a challenge hindering the rehabilitation and mitigation of the adverse effects. Therefore, the study findings inform that a community conscious of the legal procedures will quarry at a rate and manner that does not injure the environment or be in a position to restore a depleted quarry.

However, some of the $29.1 \%$ of the household heads that expressed no linkage between the two aspects argued that even when the quarry workers were aware of the rules and regulations, they did not adhere to or comply with them, leading to adverse impacts such as massive destruction of vegetation and trees. As observed, the damage was more severe where stone quarrying was the primary source of livelihood.

Other responses claimed that without enforcement of the rules and regulations by the National Environment and Management Authority and management committees, the adverse impacts would still be witnessed even when the quarry workers were well aware of those legal procedures.

\subsection{Hypothesis testing on the significance of adherence to Environmental Rules and Regulations}

It was confirmed that awareness of environmental rules and regulations on stone quarrying has a significant influence on environmental degradation experienced in the study areas as demonstrated by a Chi-square statistic $\left(\chi^{2}\right)$ of $15.665, p=0.000$ presented in Table 5 . The severity of harmful effects of stone quarrying on the environment was higher where the majority of the quarry workers were unaware or had poor knowledge of the environmental rules, principles, and regulations. 
Table 5: Awareness of Environmental Rules and Regulations on Stone Quarrying and Environmental Degradation

\begin{tabular}{|c|c|c|c|c|c|c|}
\hline \multirow{2}{*}{ Stone quarrying } & & \multicolumn{5}{|c|}{ Awareness of Environmental Rules and Regulations on Stone Quarrying } \\
\hline & & No & Yes & Total & Chi.sq. & p-value \\
\hline \multirow{3}{*}{$\begin{array}{l}\text { Severity of the negative en- } \\
\text { vironmental impacts of stone } \\
\text { quarrying activities in the area }\end{array}$} & Not severe & $10 ; 31.2$ & $22 ; 68.8$ & $32 ; 46.4$ & \multirow{4}{*}{$15.665 \mathrm{a}$} & \multirow{4}{*}{0.000} \\
\hline & Somehow severe & $10 ; 62.5$ & $6 ; 37.5$ & $16 ; 23.2$ & & \\
\hline & Very severe & $18 ; 85.7$ & $3 ; 14.3$ & $21 ; 30.4$ & & \\
\hline Total & & $38 ; 55.1$ & $31 ; 44.9$ & 69 & & \\
\hline
\end{tabular}

Source: Field Data (2020)

\section{Conclusion and recommendations}

In conclusion, less than half of the quarry workers (44.9\%) and household heads (35\%) were aware of at least one of the existing environmental rules, principles and regulations; of those, the majority had poor awareness levels. Lack of a county quarrying and mining policy and non-enforcement of the existing legal frameworks and procedures governing stone quarrying hinder extensive awareness and provide an avenue for severe impacts on the environment and human well-being in the study area. Stone quarrying operations in Tuluongoi Sublocation were carried out without compliance or adherence to the laid down laws and regulations. The quarry workers and quarry owners focused on the benefits generated at the expense of their operations' implications on the environment and residents.

This study recommends that Kenya National Environment Management Authority properly implement the existing quarrying policies, laws, and regulations while educating the public. Through the mining department, the county government of Baringo should come up with a quarrying and mining policy to complement the existing national landuse principles and laws. On realization that awareness of the current quarrying principles and regulations is low, community committees and sensitization forums to foster knowledge are necessary. The study suggests that stone quarrying companies should adhere to sustainable environmental regulations by reclaiming and rehabilitating abandoned quarries. Stone quarrying in this region requires the provision of safety gear to the workers. The use of suitable technologies that are user/environmentally friendly will make this activity a viable economic undertaking.

\section{References}

Adimo A. A., Njoroge J. B. \& Waweru S. W. (2018). Management status and perception of post quarried sites in Ndarugu, Kiambu, Kenya. Afr. J. Environ. Sci. Technol.Vol. 12(8), 268-282: https://doi.org/10.5897/AJEST2018.2474.

Auditor General. (2020). Performance Audit Report on land Conservation and Restoration of

Quarries in Kenya. Office of the Auditor General.

BCG. (2018). Baringo County Integrated Development Plan, 2018-2022. Baringo County Government.

Bowen, A., \& Pallister, J. (2006). Understanding GCSE Geography: For AQA specification A. Harcourt Education Limited. Google Scholar

Endalew, A., Tasew, E., \& Tolahun, S. (2019). Environment and Social Impacts of Stone Quarrying: South Western Ethiopia, in Case of Bahir Dar Zuria Wereda Zenzelma Kebele. Int. J. of Res. Enviro. Sci., 5(2), 29-38. http:// dx.doi.org/10.20431/2454-9444.0502005

GOK. (2010). The Occupational Safety and Health Act, 2007. Government Printer.

GOK. (2015). Environmental Management and Co-ordination Act 1999 (revised 2015). Government Printer

Hamza, S., \& Kanyama, A. (2016). Challenges of Addressing Environmental Problems due to Quarrying Operation in Uwandani Ward, Pemba. World Journal of Social Science Research Vol. 3, No. 3, 2016. https://doi. org/10.22158/wjssr.v3n3p367

K.N.B.S. (2015). Baringo County Statistical Abstract. Accessed on 15th June2020

Kindiga, W. (2017). Environmental and Land use Impacts of Quarrying along Ngong River in Embakasi (PhD thesis, University of Nairobi, Unpublished). Google Scholar

Kumar, C. H. K., Mallikarjuna, R., Singh, S. B. M. Krishna, B., Sasikala, P. \& Siva Kumar, A. V. (2014). Deterioration of Pulmonary Function in Stone Quarry Workers. Biomed. Res. (2014) Vol. 25, Issue 2. Google Scholar

Lad, R. J., \& Samant, J. (2014). Environmental and Social Impacts of Stone Quarrying-A Case Study of Kolhapur District. Int. J. Cur. Res., 6(63), 56645669. Google Scholar

Mhlongo, E. S., \& Amponsah-Dacosta, F. (2016) A Review of Problems and Solutions of Abandoned Mines in South Africa. Int. J. of Min., Recl. and Environ., 30, 279-294. https://doi.org/10.1080/17480930.2015.1044046

Mwakumanya, M. (2014). Mining and Environment: An Assessment of Mining Companies' Compliance with Environment, Health and Safety Regulations and Standards in Kwale, Kilifi and Taita Taveta Counties in the Coast Region of Kenya. Humans Rights Agenda

Natural Environment Research Council. (2017). Quarrying: Employment and the Economy. British Geological Survey.

NEMA. (2011). Integrated National Landuse Guidelines for a Sustained Societal Attributes - Infrastructure, Environmental Resources and Public Safety National Environment Management Authority.

NEP. (2013). National Environment Policy 2013. Ministry of Environment Water and Natural Resources

Smith, E., \& Rosenblum, P. (2011). Enforcing the Rules: Government and Citizen Oversight of Mining. Revenue Watch Institute. Google Scholar

Tribhuwan, R. D., \& Patil, J., (2009). Stone Quarry Workers: Social Security and Development Issues. New Delhi: Discovery Pub. House. Google scholar

Tsolaki-Fiaka, S., Bathrellos, G. D. and Skilodimou, H. D., (2018). Multi-Criteria Decision Analysis for an Abandoned Quarry in the Evros Region (NE Greece). MDPI, Land Journal 2018, 7, 43; https://doi.org/10.3390/ land7020043

Twerefou, D. K., Tutu, K., Owusu-Afriyie, J., \& Adjei-Mantey, K. (2015). Attitudes of Local People to Mining Policies and Interventions. Working paper, International Growth Center. Google Scholar 
Wells, J. \& Wall, D. (2001). The Role of Structural Adjustment Policies in the Expansion of Employment in the Building Construction Sector in Kenya and Tanzania. Urban Forum, 12, 3-4. https://doi.org/10.1007/s12132-0010008-4

Yamane, T. (1967). Statistics: An Introductory Analysis. 2nd Ed., Harper and Row, New York. Google Scholar
Zdruli, P, Paglial, M. Kapul, S. \& Cano, A. F. (2010) What We Know About the Saga of Land Degradation and How to Deal with it? Springer Netherlands, 3-14 https://doi.org/10.1007/978-90-481-8657-0_1 